\title{
Did Cresswell's 'Stream' ever run?
}

\author{
John Lee
}

In July 1934, D'Arcy Cresswell, self-appointed champion of New Zealand verse, announced a new publishing venture. In a letter to Ursula Bethell, dated July 7 of that year, he declared, 'Jim Courage of North Canterbury lately sent me 5 pounds and I have at once rushed into a publishing venture with it called "The Stream - Or Pleasant Mingling of Present affairs with that Delightful Fountain delivered us by the Ancients, to the same end of honouring Sylvan, Aquarian and Celestial Divinities." Compiled by D'Arcy Cresswell and printed by Bob Lowry. Whereof you will see the first, perhaps the only number (it depends on my friends) next month I hope... Write and tell me if you like the idea of "The Stream". It's to be something quite unusual. I feel as if I were initiating something under divine encouragement. My reply to Prof. Sinclaire will be in it. ${ }^{5}$

Helen Shaw's Chronology of Cresswell's life, preceding the selected letters she published as The Letters of D'Arcy Cresswell (1971), suggests that the first issue was published in 1934 (Shaw 12). However, I can find no other evidence that "The Stream" was in fact published, and neither the Turnbull Library nor the National Library has any record of its publication. Likewise, neither the Oxford Companion to New Zealand Literature nor the Oxford History of New Zealand Literature includes any reference to it; nor does Finlayson's biography of Cresswell, though both Shaw and Finlayson agree he had Modern Poetry and the Ideal published in that year by Lowry - through the Griffin Press according to Shaw or the Unicorn Press according to Finlayson. (On the rather entangled relationship between these two presses, which shared premises and equipment, see the note by Peter Simpson in The Oxford Companion to New Zealand Literature.) Cresswell himself makes further reference to working on "The Stream" in letters to both Bethell (August 12, 1934) and Courage (November 8, 1934) - certainly well after the hoped for "next month" - but no further references are to be found in the Selected Letters to its publication or reception.

The Alexander Turnbull Library does hold two folders of handwritten and typed material pertaining to "The Stream", which include draft copies of a poem, "Aeschylus" (MS papers 0170/083), and "A Reply to Professor Sinclaire" (MS papers 0170/084), typed and amended. There are also pencilled notes on print 
costs and layout, presumably by Lowry, written on the back of printed loose leaves of numbered poems by R.A.K. Mason. (Lowry had printed a collection of Mason's poems from 1924-29, entitled No New Thing, earlier that year, 1934.) The amended typescript indicates that fifty copies of "The Stream" were to be issued in New Zealand and a hundred copies in England, none of which were for sale.

The reply to Sinclaire was Cresswell's response to an article Sinclaire had written in June of 1932. Entitled 'A Defence of Prose', it was published in the Christchurch newspaper, The Press, in a supplement of June $18^{6}$. Sinclaire at the time was professor of English at Canterbury University College (and was involved in the preparation of the Tomorrow magazine, the first issue of which came out in July, 1934.) His 'Defence of Prose' begins, "It has often struck me that in our study and teaching of literature there is a rather notable disproportion between the amount of attention we give to discussing the technique and content of poetry and that which we give to a similar treatment of prose" (9). He goes on to argue that while, "poetry is the chief glory of our English literature", prose has not only inspired people with spiritual truth (in the West, from The New Testament and the Dialogues of Plato through to Behmen and Swedenborg), but in fact that "the history of literature might be written as the story of the triumphant advance of prose." He insists, "There is no question of superiority or inferiority. There is simply diversity of gifts." From today's perspective, it seems like a modern and forward-looking position to take.

Cresswell had devoted his life to poetry, declaring himself "a New Zealand poet" and in 1925 peddling poems door to door on a walking tour of England. William Broughton writes, "It is not as a practising poet but as a forceful and romantic advocate for New Zealand verse at a time when such an idea seemed risible that Cresswell is important" (118). Cresswell was clearly upset by Sinclaire's position, and as early as September 1932 his 'Reply' had been drafted and sent to others. Ursula Bethell wrote in that month a letter to John Schroder (on the matter of verse in the Christchurch Press), saying, "I thought the Press had surrendered to Prof Sinclaire \& was printing only prose. (D'A. C. has sent me his Reply - an admirable piece of writing I think - I am suggesting that it form a chapter in his Progress Part II. Agree not suitable for newspaper)."7

However admirable it may have been, the "Reply" was indeed, as Cresswell himself notes, "refused publication by the Press after a long and mysterious delay respecting which its author was told the typescript had been lost") ${ }^{8}$. Speaking of Sinclaire's "heresies" and "sedition", he writes, "You, Professor, are 
a Democrat in your views of literature; rather, I should say a Communist and Republican; and in your essay...there is more than enough mischief and treason to hang a mere regicide. For however Communism may be sound politics, it is no less than treason and blasphemy in respect of those higher Estates which distinguish things of the spirit". Cresswell argues strongly for the superiority of poetry over prose, concluding, "Like the sun in its greatest splendour and height, poetry beautifies and makes clearly visible all things beneath it. In this way does Dante, or any great poet, honour the masters of prose, when the ray of his spirit rests upon what they wrote." All in all, a romantic posture and a voice against the tide of history in which prose, in all its forms, has become more widely studied relative to poetry since Cresswell wrote.

Both Cresswell (born in Christchurch in 1896) and Sinclaire (born near Auckland in 1881) had spent several years as young adults overseas Cresswell largely in England and Europe (where he fought and was wounded in World War One) and Sinclaire mostly in Australia, after abandoning study at Manchester College, Oxford. Both had returned to Christchurch relatively recently, Cresswell in 1931 to lambast his city in a series of articles in the The Press (later to form part of his autobiographical Present Without Leave) before leaving for Auckland in 1933, and Sinclaire in 1932 from Western Australia to a position as professor of English at Canterbury University, bringing Winstone Rhodes with him from Australia to the University.

If "The Stream" was not in fact published, there could have been any number of reasons. Cresswell was often short of money and borrowing from his friends, and the five pounds may have been needed for other purposes; perhaps the friends he mentioned to Bethell did not support him as he had hoped, perhaps the divine encouragement lapsed, perhaps Cresswell's literary energies were directed elsewhere. Possibly, Lowry found him too difficult to work with, though he was certainly involved in the 1936 production of Cresswell's Lyttelton Harbour sequence.

Cresswell was indeed an eccentric character and could be difficult to work with. Denis Glover was one of several of his friends who wrote about him in a series of memories in Landfall after his death. Referring to his Caxton Press publication of Cresswell's Eena Deena Dynamo in 1936, Glover wrote, "There were 140 copies at 2 s. $6 \mathrm{~d}$., and never have I dealt with such a difficult author... There was also the ms. of a pamphlet called Night Attack, justifying an approach to sex not currently acceptable in Canterbury. Clearly by Cresswell, it was to be attributed to a North Island friend whose assent seemed not to be 
given. Things being as they were, publication was declined" (Glover 347).

Ironically, Cresswell's prose writings, in particular his autobiographical The Poet's Progress (1930) and Present Without Leave (1939), are better remembered than his verse and, according to Finlayson, "due to the perfection of their style they tend to be more highly regarded" (5). Cresswell's proposed "Stream" may have run dry but the ideas and the energy behind it were part of what Monte Holcroft referred to as the "Deepening Stream" of New Zealand culture that had its firm foundations laid in the outpouring of literary production and debate in the 1930s.

\section{Works Cited}

Broughton, William. 'D'Arcy Cresswell' in The Oxford Companion to New Zealand Literature. Ed. Roger Robinson and Nelson Wattie. Auckland: Oxford University Press, 1998.

Finlayson, Roderick. D’Arcy Creswell. New York: Twayne Publishers, 1972.

Glover, Dennis. 'D’Arcy Cresswell, by his Friends.' Landfall 56 (December 1960): 347.

Holcroft, M.H. The Deepening Stream. Christchurch: Caxton Press, 1940.

Shaw, Helen, ed. The Letters of D'Arcy Cresswell. Christchurch: University of Canterbury, 1971.

Simpson, Peter. 'The Griffin Press' in The Oxford Companion to New Zealand Literature. Ed. Roger Robinson and Nelson Wattie. Auckland: Oxford University Press, 1998.

Sinclaire, F.W. Lend Me Your Ears: Essays. Christchurch: Caxton Press, 1942; rptd Wellington: Progressive Publishing Society, 1943. 
5 Creswell's letters to Bethell are preserved in her papers in the MacMillan Brown Library, Christchurch, MS 38/3.

6 Alexander Turnbull Library, Cresswell MS papers 0170/083.

7 September 15, 1932. Bethell's letters to Schroder are preserved in the Alexander Turnbull Library, Wellington, fMS 018.

8 Alexander Turnbull Library, Cresswell MS papers 0170/083. 